\begin{tabular}{|c|c|c|c|c|c|c|}
\hline \multirow{3}{*}{$\begin{array}{l}\text { 2. ECN Category } \\
\text { (mark one) } \\
\text { Supplemental } \\
\text { Direct Revision } \\
\text { Change ECN } \\
\text { Temporary } \\
\text { Standby } \\
\text { Supersedure } \\
\text { Cancel/Void }\end{array}$} & \multirow{3}{*}{$\begin{array}{r}{[]} \\
{[X]} \\
{[]} \\
{[]} \\
{[]} \\
{[]} \\
{[]}\end{array}$} & \multicolumn{2}{|c|}{$\begin{array}{l}\text { 3. Originator's Nane, Organization, MSIN, } \\
\text { and Telephone No. } \\
\text { D. E. Skoglie } 8 H 400 / R D 1 C A \\
\text { S3-24 } 373-7496\end{array}$} & \multicolumn{2}{|c|}{$\begin{array}{l}\text { 3a. USO Required? } \\
\text { [] Yes }[X] \text { No }\end{array}$} & $\begin{array}{l}\text { 4. Date } \\
\text { March 31, } 1996\end{array}$ \\
\hline & & \multicolumn{2}{|c|}{$\begin{array}{l}\text { 5. Project Title/No./Work Order No. } \\
\text { NA }\end{array}$} & \multicolumn{2}{|c|}{$\begin{array}{l}\text { 6. Bldg./Sys./Fac. No. } \\
\text { NA }\end{array}$} & $\begin{array}{c}\text { 7. Approval Designator } \\
E Q\end{array}$ \\
\hline & & \multicolumn{2}{|c|}{$\begin{array}{l}\text { 8. Document Numbers Changed by this ECN } \\
\text { (includes sheet no. and rev.) } \\
\text { WHC-SD-EN-AP-122, Rev } 0\end{array}$} & \multicolumn{2}{|c|}{$\begin{array}{l}\text { 9. Related ECN No(s). } \\
\qquad N / A\end{array}$} & $\begin{array}{l}\text { 10. Related PO No. } \\
\text { NA }\end{array}$ \\
\hline \multirow{2}{*}{\multicolumn{2}{|c|}{$\begin{array}{l}\text { 11a. Modification Work } \\
\text { [] Yes (fill out Blk. } \\
11 \mathrm{~b} \text { ) } \\
{[X] \text { No (NA BLks. 11b, }} \\
11 \mathrm{c}, 11 \mathrm{~d})\end{array}$}} & \multirow[t]{2}{*}{$\begin{array}{l}\text { 11b. Work Package } \\
\text { No. } \\
\text { NA }\end{array}$} & \multirow{2}{*}{\multicolumn{2}{|c|}{$\begin{array}{l}\text { 11c. Modification Work Complete } \\
\text { NA }\end{array}$}} & \multicolumn{2}{|c|}{$\begin{array}{l}\text { 11d. Restored to Original Condi- } \\
\text { tion (Temp. or Standby ECN only) } \\
\text { NA }\end{array}$} \\
\hline & & & & & & er si \\
\hline
\end{tabular}

12. Description of Change

WHC-SD-EN-AP-122, Rev 1, "Hanford Well Remediation and Decommissioning Plan" was Reved

(1). The document does not contain change bars as substantial formatting and organizational changes were incorporated to clarify and update information.

13a. Justification (mark one)

Criteria Change [] Design Improvenent

As-Found

[] Facilitate const

[] Environmental

Const. Error/Onission

[] Facility Deactivation

[]

Design Error/Omission

13b. Justification Details

WHC-SD-EN-AP-122 is utilized to formalize and incorporate the approval process. Rev 1 was initiated to reformat/organize and change sentence structure to clarify meaning.

The intent of this Rev (1) is not to change requirements or policy.

14. Distribution (include name, MSIN, and no. of copies)

See Distribution Sheet

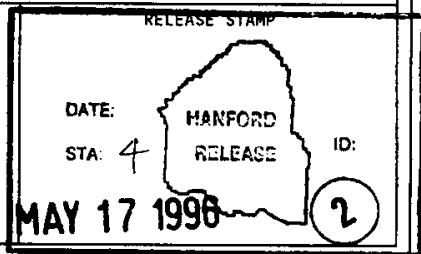

$A=7$ 


\section{Hanford Well Remediation and Decommissioning Plan}

D.E. Skoglie

WHC, Richland, WA 99352

U.S. Department of Energy Contract DE-AC06-87RL10930

$\begin{array}{llll}\text { EDT/ECN: } & \text { ECN-611439 } & \text { UC: } 2050 \\ \text { Org Code: } & 8 H 400 & \text { Charge Code: } & \text { RD1CA } \\ \text { B\&R Code: } & \text { EW3120100 } & \text { Total Pages: } & 16\end{array}$

Key Words: Remediation, Decommission

Abstract: This plan provides the requirements for conducting well remediation and decommissioning activities.

TRADEMARK DISCLAIMER. Reference herein to any specific comercial product, process, or service by trade name, trademark, manufacturer, or otherwise, does not necessarily constitute or imply its endorsement, recommendation, or favoring by the United States Government or any agency thereof or its contractors or subcontractors.

Printed in the United States of America. To obtain copies of this document, contact: WHC/BCS

Document Control Services, P.0. Box 1970, Maitstop H6-08, Richland HA 99352, Phone (509) 372-2420;

Fax (509) 376-4989.
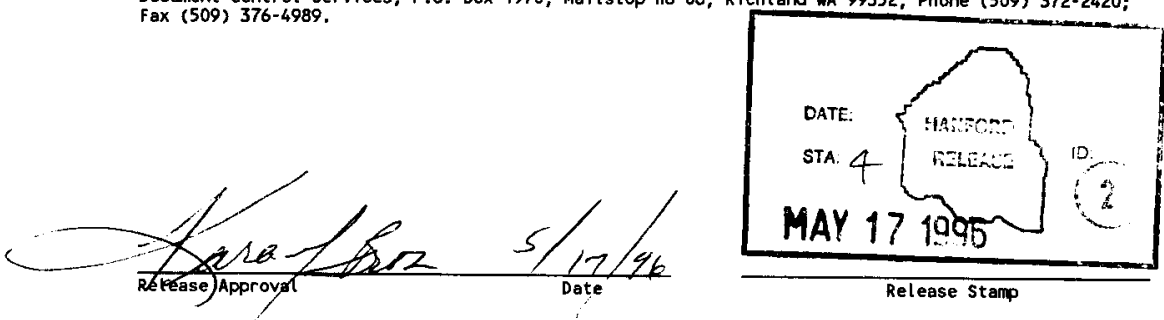

Release Stamp

\section{Approved for Public Release}


(2) Title

Hanford Well Remediation and Decommissioning Plan CHANGE CONTROL RECORD

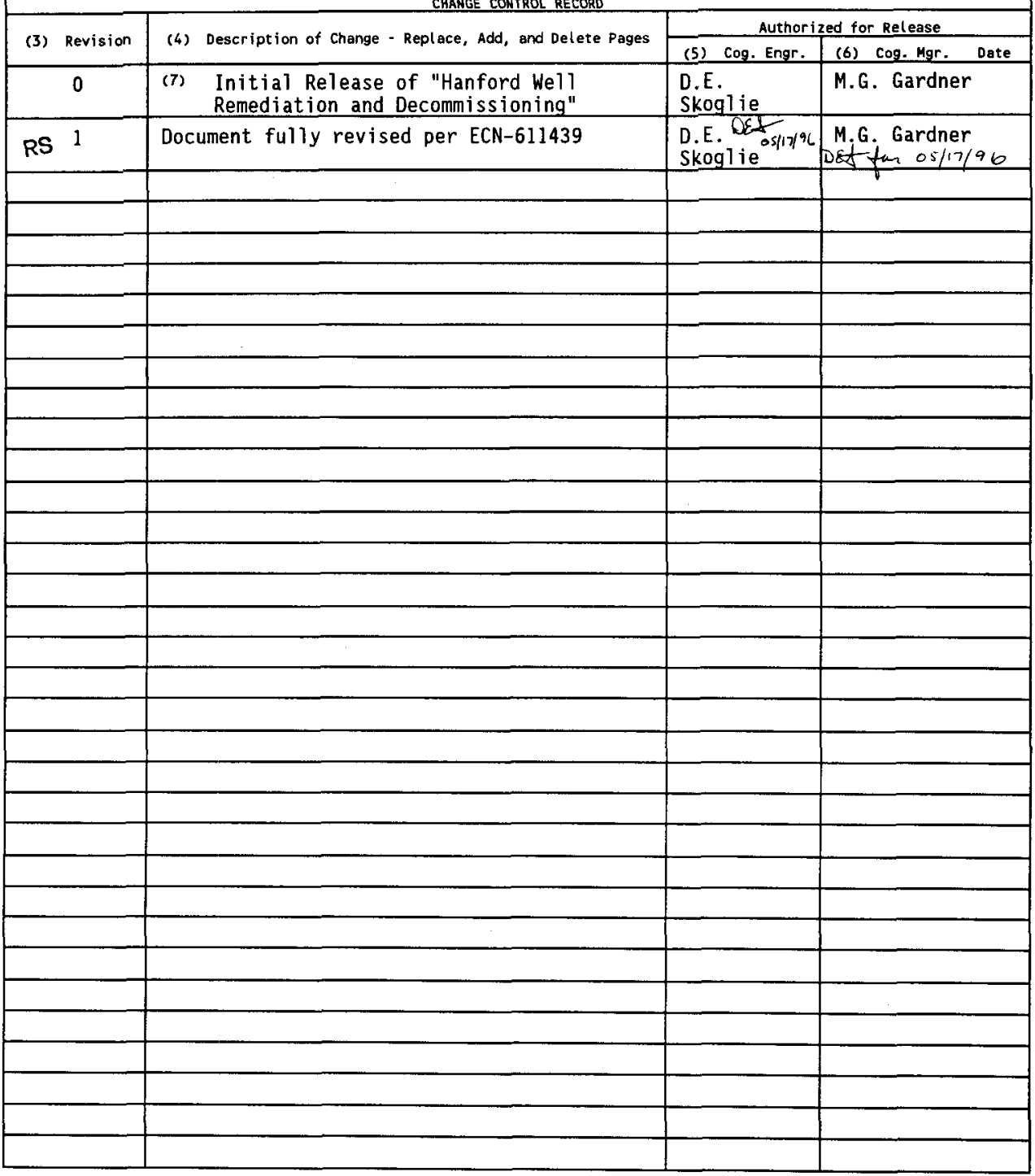


TABLE OF CONTENTS

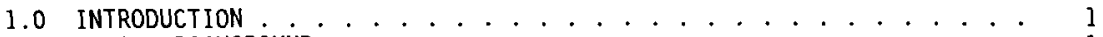

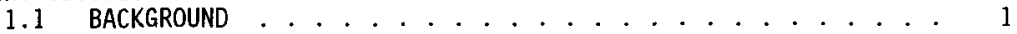

2.0 REFERENCED CODES, STANDARDS, AND SPECIFICATIONS ........ 2

2.1 FEDERAL REGULATIONS AND GUIDANCE ............. 2

2.2 WASHINGTON ADMINISTRATIVE CODE (WAC .......... 3

2.3 WESTINGHOUSE HANFORD COMPANY ............. 3

3.0 HANFORD SITE WELL USE . . . . . . . . . . . . . . 3

3.1 GROUNDWATER SURVEILLANCE AND MONITORING PROGRAMS ...... 3

3.1 .1 Site-Wide Surveillance ............ 3

3.1 .2 Operational Monitoring ........... 4

3.1.3 Resource Conservation and Recovery Act (RCRA) Permit . 4

3.1.4 Comprehensive Environmental Response, Compensation, and Liability Act (CERCLA) Monitoring and Site

Characterization ........... 5

3.1.5 Washington 216-Permitted Facilities . . . . . 5

3.1.6 Washington Underground Storage Tank Monitoring . . . . 5

3.2 VADOSE ZONE CHARACTERIZATION AND MONITORING ........ 5

3.3 WATER SUPPLY WELLS .................... 6

3.4 RESEARCH OR SPECIAL PURPOSE WELLS ............ 6

3.5 NON-DOE CONTRACTOR WELLS . . . . . . . . . . . 6

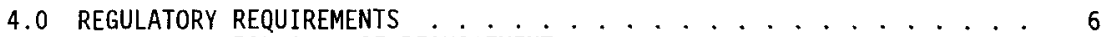

4.1 FEDERAL AND DOE REQUIREMENTS . . . . . . . . . 6

4.2 STATE STANDARDS FOR WELL CONSTRUCTION, MAINTENANCE AND ABANDONMENT . . . . . . . . . . . . . 6

4.3 HANFORD FEDERAL FACILITY AGREEMENT AND CONSENT ORDER $\because . \quad 7$

4.4 HANFORD FACILITY RCRA PERMIT ............ 7

4.5 OTHER STATE OR RCRA PERMITS .............. . . 7

4.6 USE OF EXISTING WELLS .................. 7

4.7 ENVIRONMENTAL COMPLIANCE . . . . . . . . . . . . . 8

5.0 REMEDIATION AND DECOMMISSIONING ACTIVITY MANAGEMENT AND CONTROL . . 8

5.1 IDENTIFICATION OF WELL REQUIREMENTS . .......... 8

5.2 DESIGN REVIEW AND APPROVAL $\ldots \ldots$

5.3 CONTRACTOR INTERFACE/RESPONSIBILITIES . . . . . . . . 10

5.4 CONDUCT OF OPERATIONS ............................ 10

5.4.1 Fitness-For-Use . . . . . . . . . . . . . 10

5.4.2 Remediation Specifications . . . . . . . . . . 10

5.4.3 Decommissioning Requirements ........... . 10

5.5 EFFLUENT MONITORING AND WASTE MANAGEMENT . . . . . . . . 12

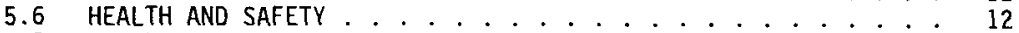

5.7 PLANNING AND BUDGETING ................ 12

5.7.1 Work Breakdown Structure .............. 12

5.7.2 Cost Account Management . . . . . . . . . . . . . 12

5.7 .3 Change Control ................. 12

5.8 REPORTING . . . . . . . . . . . . . . . . . . . 13 


\section{WHC-SD-EN-AP-122, Rev. 1}

5.8.1 WAC 173-160 Reporting . . . . . . . . . . . . . . 13 5.8.2 Activity Documentation and Hanford Site Well Database. 13 5.8.3 Summary Reports . . . . . . . . . . . . . . . . . 13

5.8.4 Annual Report . . . . . . . . . . . . . . . . . . 13 
WHC-SD-EN-AP-122, Rev. 1

\subsection{INTRODUCTION}

Protection of Hanford Site groundwater and assessment of it's use (or contamination) upon public safety are required by federal and state regulations and U.S. Department of Energy (DOE) policy, ("Hanford Site Groundwater Protection Management Program," DOE, 1989). Compliance with constraints applicable to the use of existing wells requires assessment as to the suitability for use and needs for rehabilitation, remediation, or decommissioning of existing groundwater wells and other boreholes potentially affecting aquifers beneath the Hanford Site. This plan provides the requirements for conducting well remediation and decommissioning activities.

\subsection{BACKGROUND}

Approximately 4,696 groundwater wells and vadose zone boreholes have been drilled on the Hanford Site. Approximately 3,286 wells still exist (WHC-SD-EN-DP-071, Rev 1, Hanford We11 Custodians). Most of these boreholes were drilled prior to 1987 and do not conform to presently accepted construction standards intended to protect groundwater resources (Ecology, 1990). A majority of the wells installed since 1987 were constructed to current standards for well construction which mandate seals between the permanent casing and the formation to prevent potential migration of contaminated liquid.

The older wells were generally drilled by cable tool rigs using the drill and drive method. This method involves drilling while driving casing fitted with a drive shoe to prevent friction locking of the casing. Upon reaching desired depth, the casing was usually perforated to allow inflow of groundwater. Generally, no surface or annular seals were installed between the formation and casing. Wells that lack seals can allow migration of contaminants from surface to the water table. The lateral flow derived from cribs or waste tank leaks can also migrate along the casing, potentially reaching groundwater.

Contaminants and other sources have moved down the casing and into the groundwater in the past. In response to this problem, a program of surface/annular seal installation was carried out from 1976 through 1985. The program involved perforation of existing casing and installation of grouted inner liners in several hundred wells in the 200 Areas. Wells were selected based upon proximity to potential contamination sources. Documentation of this process was limited to archived drilling logs.

The majority of Hanford wells are still in use or are abandoned (Table 1). Over 500 ground water wells have gone dry due to infiltration of sediments into the screened interval or lowering of the water table. 
WHC-SD-EN-AP-122, ReV. 1

TABLE 1. HANFORD SITE WELL STATUS

\begin{tabular}{|c|c|}
\hline \multicolumn{1}{|c|}{ HANFORD SITE WELL STATUS } \\
\hline CURRENT STATUS & TOTAL WELLS \\
\hline ABANDONED & 1,245 \\
\hline AWAITING DECOMMISS IONING & 33 \\
\hline CLAIMED & 417 \\
\hline DESTROYED & 136 \\
\hline DRILLING IN-PROCESS & 7 \\
\hline IN-USE & 2,417 \\
\hline ORPHAN & 395 \\
\hline PRIVATE & 2 \\
\hline PRIVATE IN-USE & 8 \\
\hline UNABLE TO LOCATE & 33 \\
\hline UNKNOWN & 4,696 \\
\hline TOTAL WELLS TRACKED & 3 \\
\hline \hline
\end{tabular}

NOTE: The numbers in Table 1 above were tallied January 1996.

\subsection{REFERENCED CODES, STANDARDS, AND SPECIFICATIONS}

\subsection{FEDERAL REGULATIONS AND GUIDANCE}

DOE, 1989, Hanford Site Groundwater Protection Management Program, DOE/RL-89-12, U.S. Department of Energy, Rich1 and, Washington.

Ecology, EPA, and DOE, 1990, Hanford Federal Facility Agreement and Consent Order, 2 Vols., Washington State Department of Ecology, U.S. Environmental Protection Agency, and U.S. Department of Energy, 0lympia, Washington.

DOE, 1988, General Environmental Protection Program, DOE Order 5400.1, U.S. Department of Energy, Washington, D.C. 
WHC-SD-EN-AP-122, Rev. 1

\subsection{WASHINGTON ADMINISTRATIVE CODE (WAC)}

Ecology, 1990a, Minimum Standards for Construction and Maintenance of Wells, WAC 173-160, Washington State Department of Ecology, 01 ympia, Washington.

Ecology, 1990b, State Waste Discharge Permit Program, WAC 173-216, Washington State Department of Ecology, 01 ympia, Washington.

\subsection{WESTINGHOUSE HANFORD COMPANY}

WHC, 1988a, Management Control System, WHC-CM-2-5, Westinghouse Hanford Company, Richland, Washington.

WHC, 1988b, Environmental Compliance, WHC-CM-7-5, Westinghouse Hanford Company, Richland, Washington.

WHC, 1988c, Environmental Investigations and Site Characterization

Manua 7, WHC-CM-7-7, Vo1. 1, Westinghouse Hanford Company,

Richland, Washington.

EII-1.6, "QA Record Processing"

EII-6.6, "Resource Protection We7l Characterization and Evaluation"

EII-6.10, "Abandoning/Decommissioning Groundwater Wells."

WHC, 1988d, Vadose Zone Well Remediation Report: An Assessment

Using Existing Data, WHC-SD-EN-AP-009, Rev 0, Westinghouse Hanford Company, Richland, Washington.

WHC, 1992, Specification for Remediation of Existing Resource Protection Wel7s, WHC-S-0115, West inghouse Hanford Company, Richland, Washington.

WHC, 1994, WHC-SD-EN-AP-161, Rev 0, Fitness-for-Intended-Use Evaluation Recommendations for Hanford Site 600 Area Wells.

WHC, 1995, WHC-SD-EN-DP-071, Rev 1, Hanford We71 Custodians.

\subsection{HANFORD SITE WELL USE}

Several programs presently construct and/or utilize existing and newly drilled wells to provide characterization and groundwater monitoring data (DOE, 1989). Table 2 provides a current tabulation of existing wells and corresponding custodians. The programs are summarized in the following paragraphs.

\subsection{GROUNDWATER SURVEILLANCE AND MONITORING PROGRAMS}

\subsubsection{Site-Wide Surveillance}

The independent site-wide surveillance program for the Hanford Site is conducted by Pacific Northwest National Laboratory. This program monitors the effects, if any, of DOE activities at Hanford to onsite and offsite environmental and natural resources. At the present time, over 795 monitoring wells on the Hanford Site are used to 
assess the impact of specific facilities and to track the movement of contaminant plumes from past practice disposals. Many of the wells used in this assessment are selected from the operational monitoring networks to define site-wide contaminant distribution patterns. Both chemical and radiological constituents are examined.

\subsubsection{Operational Monitoring}

The operational groundwater monitoring program conducted by Westinghouse Hanford Company (WHC), which may be considered "near-field monitoring," addresses groundwater conditions in

TABLE 2. HANFORD SITE WELL USE

\begin{tabular}{||c|c|}
\hline \multicolumn{1}{|c|}{ HANFORD SITE WELL USE } & NUMBER OF WELLS \\
\hline Bechtel Hanford Inc. & 561 \\
\hline City Well & 12 \\
\hline Kaiser Engineers Hanford & 7 \\
\hline S.C. Benton Irrigation District/State Wildlife & 2 \\
\hline Pacific Northwest National Laboratories & 1,203 \\
\hline U.S. Ecology & 5 \\
\hline Westinghouse & 3,291 \\
\hline Other & 45 \\
\hline \multicolumn{1}{|c|}{ TOTAL } \\
$\begin{array}{l}\text { NOTE: The overal1 we11 total in TABLE 2 is greater } \\
\text { than the total number of wells 1isted since a single } \\
\text { we11 may be In-Use by multiple site contractors. }\end{array}$ \\
\hline
\end{tabular}

and adjacent to reactor and chemical processing operations in the $100,200,300,400$ and 1100 areas. Operational groundwater monitoring has been carried out at the Hanford Site since the early days of the project.

\subsubsection{Resource Conservation and Recovery Act (RCRA) Permit Characterization and Monitoring}

The RCRA groundwater monitoring program conducted by WHC currently involves site-specific monitoring and/or well installation at 20 facilities under EPA interim status 
WHC-SD-EN-AP-122, Rev. 1

regulations. Over 250 new RCRA-compliant monitoring we $11 \mathrm{~s}$ have been installed for this purpose.

3.1.4 Comprehensive Environmental Response, Compensation, and Liability Act (CERCLA) Monitoring and Site Characterization

Several CERCLA "groundwater operable units" have been identified at Hanford. Monitoring wells within these units are located so as to define the nature and extent of contaminant plumes.

Use of data from existing wells is generally included as a part of a specific groundwater operable unit work plan. Wells selected for this purpose often must be remediated to allow for their use. Other existing wells within the operable unit may be identified for remediation or decommissioning. The Environmental Restoration Contractor (ERC) has responsibility for wells associated with programs conducted under CERCLA.

\subsubsection{Washington 216-Permitted Facilities}

Permits administered by Washington Administrative Code (WAC) 173-216 (Ecology, 1990b) are required for facilities that dispose of liquid waste streams to the ground. These permits require sampling and analysis plans and groundwater impact assessments. Existing vadose and groundwater wells are used for active and inactive crib monitoring.

\subsubsection{Washington Underground Storage Tank Monitoring}

Groundwater monitoring is required for underground storage tanks containing petroleum products and "other regulated substances."

\subsection{VADOSE ZONE CHARACTERIZATION AND MONITORING}

Several hundred vadose zone wells are used by WHC to monitor subsurface waste storage and disposal sites to provide early warning of potential waste movement that could signal potential or future groundwater contamination problems. Many of these wells may require remediation or decommissioning to preclude groundwater resource contamination caused by wel1 construction inadequacies (WHC, 1988d). 


\subsection{WATER SUPPLY WELLS}

A limited number of water supply wells are present on the Hanford Site. The wells are used for water supply at isolated facilities or as emergency facility backup water supplies. These wells may require rehabilitation or remediation as determined by the users.

\subsection{RESEARCH OR SPECIAL PURPOSE WELLS}

Several series of research or special purpose wells have been drilled on the Hanford Site. The wells include stratigraphic and hydrologic investigation boreholes, reactor siting study boreholes and destroyed seismic test holes. Selected wells may require rehabilitation, reconfiguration or remediation.

\subsection{NON-DOE CONTRACTOR WELLS}

Several non-D0E contractors such as the Washington Public Power Supply System, Skagit Power, Siemens Nuclear and US Ecology have constructed characterization and facility monitoring wells, which may be selected for future remediation or decommissioning.

\subsection{REGULATORY REQUIREMENTS}

\subsection{FEDERAL AND DOE REQUIREMENTS}

Applicable DOE, other federal, and Washington state statutory requirements governing use and construction of groundwater wells are summarized in Hanford Site Groundwater Protection Management Program (DOE, 1989).

This document also illustrates the groundwater protection strategy required by DOE Order 5400.1 (DOE, 1988). One of the elements of this strategy is a management program for groundwater protection and remediation. This management program requires that well remediation, decommissioning and maintenance plans be developed to support operational, RCRA and CERCLA groundwater monitoring requirements.

\subsection{STATE STANDARDS FOR WELL CONSTRUCTION, MAINTENANCE AND ABANDONMENT}

The State of Washington Department of Ecology (Ecology) has issued standards governing groundwater well design, maintenance, construction, and abandonment in WAC 173-160 (Ecology, 1990a). These standards will be applied to the remediation and decommissioning of existing wells.

The term decommissioning is used in this plan as equivalent to the properly completed and documented abandonment of a groundwater or resource protection well. 
WHC-SD-EN-AP-122, Rev. I

WAC 173-160 may be used to evaluate the fitness for intended use and impact upon groundwater resources of existing boreholes. Provisions exist within the standard for variances allowing alternative construction specifications upon prior application on a case-by-case basis to Ecology.

\subsection{HANFORD FEDERAL FACILITY AGREEMENT AND CONSENT ORDER}

The Hanford Federal Facility Agreement and Consent Order (Ecology, EPA, and DOE, 1990), commonly known as the Tri-Party Agreement, establishes requirements for the conduct of environmental investigations on the Hanford Site. Functional design requirements for use of existing wells are developed based upon approved decisions reached under this agreement.

\subsection{HANFORD FACILITY RCRA PERMIT}

The Hanford Facility RCRA Permit became effective and enforceable on September 28, 1994. The Permit is written in two parts. The first part is the Dangerous Waste Portion of the Resource Conservation and Recovery Act Permit for the Treatment, Storage, and Disposal of Dangerous Waste and is issued by the Washington State Department of Ecology (Ecology). The second part is the Hazardous and Solid Waste Amendments Portion of the Resource Conservation and Recovery Act Permit for the Treatment, Storage, and Disposal of Hazardous Waste, and is issued by the Environmental Protection Agency (EPA). Part one specifies requirements for the inspection, maintenance, remediation, and decommissioning of wells subject to the Permit in Part II $F$. The Permit requires that for wells subject to the permit, permittee shall achieve full compliance with Chapter 173-160 WAC and Chapter 18.104 RCW by the year 2012 (Ecology, EPA, and DOE, 1990) Part two of the Permit specifies well construction, maintenance and decommissioning requirements in Attachment A part B.C.

\subsection{OTHER STATE OR RCRA PERMITS}

Permits for other RCRA or WAC 173-216 facilities may apply to this plan or the use of existing wells. Applicable requirements will be incorporated into this plan when identified.

\subsection{USE OF EXISTING WELLS}

The Ecology and the EPA developed a policy in response to the issue of many existing wells for.RCRA and CERCLA work. This policy, "Data Quality Objectives and Remediation Criteria For RCRA and CERCLA wells at the Hanford Site June 1990," was transmitted to DOE/RL on July 16, 1990. The policy specifies the minimum remediation requirements for existing wells proposed for use in RCRA or CERCLA monitoring programs. 


\subsection{ENVIRONMENTAL COMPLIANCE}

The Environmental Compliance Manual (WHC, 1988b) establishes overall environmental compliance requirements for WHC. Applicable requirements are incorporated into operating procedures and specifications.

\subsection{REMEDIATION AND DECOMMISSIONING ACTIVITY MANAGEMENT AND CONTROL}

\subsection{IDENTIFICATION OF WELL REQUIREMENTS}

Wells identified to have a potential problem, e.g., do not meet WAC 173160 construction requirements, have no use, etc., will be evaluated to determine extent of problem and mitigation required. Additionally, federal or state regulators may identify wells for evaluation. Subsequently, request(s) for remediation or decommissioning activities may be performed on boreholes or groups of boreholes.

Each well proposed for use or decommissioning is evaluated and placed into action categories based upon present and future use, degree of environmental impact, location and construction characteristics. The criteria used includes:

\section{Potential or Present Use:}

- Groundwater quality analysis;

- Water level measurements;

- Geophysical logging or monitoring;

- Water supply;

- Groundwater or soil remediation;

- Soil characteristics; and

- No known use.

\section{Environmental Effect:}

- Potential affect on groundwater resources, particularly the Columbia River, confined aquifers and groundwater not presently contaminated;

- Demonstrated contamination migration or aquifer interconnection; and

- Category list.

\section{Location and Construction:}

- Spatial location with respect to permitted facilities or RCRA site requirements;

- Well configuration;

- Well construction materials; and

- Available construction maintenance records. 
Action Categories include:

- No action required, well is acceptable for defined data quality objective(s);

- Rehabilitation to original condition required to attain data quality objective(s) and fulfill criteria for Intended Use;

- Remediation required to protect groundwater resources or to attain required data quality objective(s); and

- Decommissioning required, the well cannot be remediated or has no documented present or future use.

Wells within each Action Category are evaluated and assigned a priority status. The wells are scheduled for Use, Remediation or Abandonment.

\subsection{DESIGN REVIEW AND APPROVAL}

The mechanism for approval under the Tri-Party Agreement (Ecology, EPA, and DOE, 1990) of proposed use or decommissioning of groundwater wells requires identification of data quality objectives by user groups, selection of existing well data points, compilation of well construction and sampling data, and preparation of a schematic proposal for remediation or abandonment of specific wells.

This schematic proposal addresses present conditional, recommended actions and suggested well completion geometry on a case-by-case basis. It is then transmitted to representatives of all other concerned Hanford Site users for review and approval.

When strict compliance with the requirements of WAC $173-160$ is not possible for the proposal, application may be made to Ecology for approval of a variance prior to the work being done.

The proposal can be presented to DOE, EPA and/or Ecology during regularly scheduled overview meet ings for comment and concurrence. This review and concurrence is considered equivalent to the well construction variance process allowed in WAC 173-160-020. Approved meeting minutes can act as the implementing approval document.

In some cases concurrence cannot be provided during meetings. Approval and additional guidance, if required, is provided by specific correspondence between Ecology, EPA, and DOE. This correspondence may be identified as an action item during overview meetings.

Past correspondence and historical data relating to design requirements are a part of existing functional design requirements. This information is used to generate schematic drawings and fitness-for-intended-use evaluations for wells under consideration for use, remediation, or abandonment. 
WHC-SD-EN-AP-122, Rev. 1

\subsection{CONTRACTOR INTERFACE/RESPONSIBILITIES}

Integration and coordination of Hanford Site well remediation and decommissioning activities is necessary to fulfill the requirements of the Hanford Site Groundwater Management Program (DOE, 1989).

WHC is functionally responsible for management, field direction and documentation of groundwater we 11 remediation and decommissioning activities on the Hanford Site. The responsible function also coordinates required design review and approval for use of existing groundwater wells.

Figure 1 provides a process chart for completion of identified requirements for groundwater well remediation or decommissioning.

\subsection{CONDUCT OF OPERATIONS}

All fitness-for-use assessments and field operations are planned and conducted according to approved procedures and specifications. Governing procedures are Environmental Investigations Instructions (EIIs) contained in WHC-CM-7-7 (WHC, 1988C). Specific EIIs are cited within this plan as applicable.

\subsubsection{Fitness-For-Use}

Assessment of fitness-for-intended use of identified we11s is done according to EII 6.6. This EII also provides the mechanism for obtaining review and approval of proposed schematic remediation or decommissioning methods. This review and approval process involves all potential users and involved groups. A Supporting Document (SD), "Fitness-for-Intended-Use Evaluation Recommendations for Hanford Site 600 Area We1ls," WHC-SD-EN-AP-161, Rev 0., (WHC, 1994) has been prepared that formalizes the Fitness-For-Use documentation and incorporates the approval process.

\subsubsection{Remediation Specifications}

A generic remediation specification, "Specification for Remediation of Existing Resource Protection Wells, "has been prepared for groundwater wells requiring remediation (WHC., 1992). Remediation field activities are controlled by EII 8.3.

\subsubsection{Decommissioning Requirements}

Decommissioning requirements are contained in WAC 173-160, EII 6.10 and borehole specific instructions implemented by the field operations crews. 
WHC-SD-EN-AP-122, Rev. 1

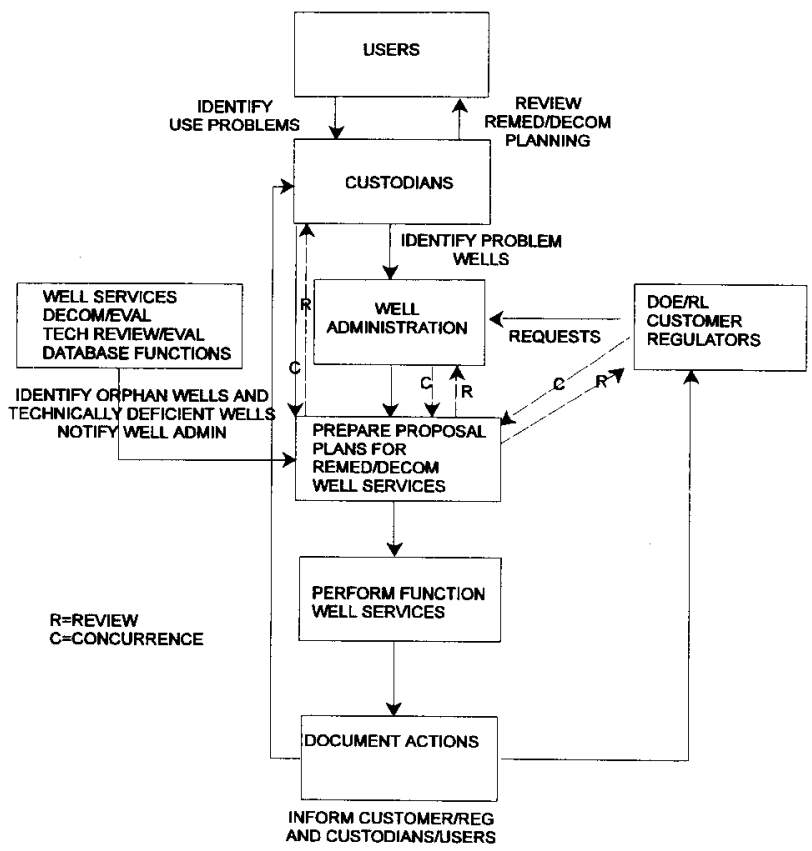

Figure 1. Process Chart for Remediation/Decommissioning of Hanford Site Wells 
WHC-SD-EN-AP-122, Rev. 1

\subsection{EFFLUENT MONITORING AND WASTE MANAGEMENT}

Specifications and applicable EIIs, in section 4.0 and 5.0 of WHC $1988 \mathrm{C}$, address the effluent monitoring and waste management requirements of WHC-CM-7-5 (WHC, 1988b) and provide for control and disposition of fluids and waste produced during maintenance, remediation or decommissioning of wells.

\subsection{HEALTH AND SAFETY}

Health and safety requirements are addressed in specifications and instructions for al1 maintenance, remediation and decommissioning activities. These requirements may include special training, field safety, radiological safety and hazardous waste safety. Excavation permits and/or a Job Hazard Analysis are obtained for work as needed.

\subsection{PLANNING AND BUDGETING}

Work within this activity is controlled under the WHC Management Control System as defined in WHC-CM-2-5 (WHC, 1988a).

\subsubsection{Work Breakdown Structure}

Work within this activity is a part of the WHC product oriented Work Breakdown Structure. An element of the applicable work breakdown structure is a specific cost Account Authorization annually developed for well rehabilitation, remediation and decommissioning. The cost account authorization contains scope of work, budget, identified milestones and a Level III schedule for attainment of the milestanes.

\subsubsection{Cost Account Management}

The Cost Account Manager prepares a Cost Account Plan containing the detailed time-phased planning, monitoring, and controlling of the cost account work. The cost account plan is then input into the Financial Data System for tracking to assure that planned work is completed on schedule and within budget.

\subsubsection{Change Control}

Changes to schedule, budget or baseline are as specified in WHC-CM-2-5. 


\subsection{REPORTING}

\subsubsection{WAC 173-160 Reporting}

WAC 173-160-050 requires that every we11 contractor, within thirty days after completion (or alteration) of a well, submit a complete record on the construction or alteration of the we11 to Ecology.

Well contractors must notify Ecology of their intent to construct, re-construct, or abandon a well at least seventytwo hours before starting work by completion of a well construction notification card (Start card).

Abandonment procedures for resource protection wells must be recorded on a form provided by Ecology. Well abandonment must be recorded and reported to Ecology within thirty days of abandonment.

\subsubsection{Activity Documentation and Hanford Site Well Database}

Well remediation and decommissioning field activities are documented as required by EII 1.6 and other applicable EIIs. Summaries of reviewed field activity reports are entered into a Hanford Site Well Database system maintained by WHC's Well Services.

\subsubsection{Summary Reports}

Summary activity reports will be provided to representatives of wel1 use organizations. Site contractors and DOE/RL generally meet on a monthly basis to discuss well issues.

\subsubsection{Annual Report}

An annual report summarizing remediation and decommissioning activities will be prepared and issued for public clearance within 90 days after the end of each fiscal year. 


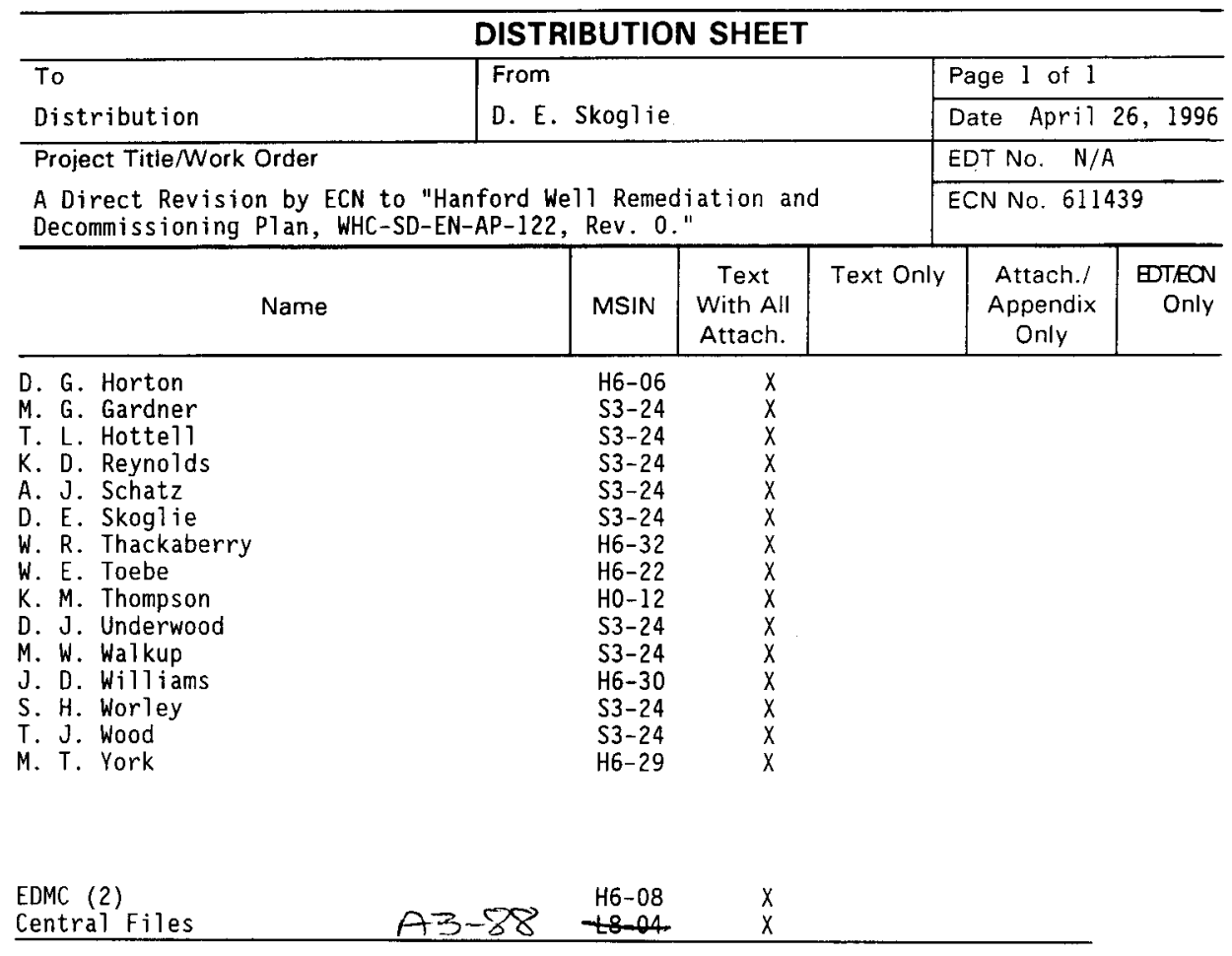

